\title{
SUSTAINABLE DEVELOPMENT IN ISLAND COMMUNITIES: THE CASE STUDY OF POSTIRA
}

\author{
Željka Tonković ${ }^{1}$, Jelena Zlatar $^{2}$
}

Received 19 December 2013; Accepted 9 July 2014

\begin{abstract}
The article shows the results of the case study of Postira, a village and a municipality on the island of Brač (Croatia) and presents a positive example of sustainable community development on islands in the post-transition social context. Based on the theory of sustainable local community development and its four pillars (economic, ecological, social and cultural), we analyse both the secondary data and the primary data collected from semi-structured interviews with the key actors of local development. The study shows that economic, ecological, social and cultural domaines are connected in Postira which allows for sustainable development of the place. By examining various aspects of sustainable development in Postira, we present the general framework of sustainable island development. It is based on integral development of the local community on sustainability principles, it defines key processes and guidelines and can be applied to rural and island areas, taking into account the specificities of each community.
\end{abstract}

Keywords: sustainable community development, island community, Adriatic islands, posttransition period.

Sažetak: Članak predstavlja rezultate studije slučaja općine Postira na otoku Braču (Hrvatska), koja su odabrana kao pozitivan primjer održivog otočkog razvoja. Teorijski, rad se temelji na teoriji održive lokalne zajednice i njezine četiri dimenzije (ekonomska, ekološka, socijalna i kulturna). Empirijski podaci prikupljeni su analizom dokumentacije i polustrukturiranim intervjuima s ključnim akterima lokalnog razvoja. Studija je pokazala kako u Postirima postoji povezanost navedenih dimenzija održivosti što omogućava razvoj mjesta u smjeru održivosti. Na temelju analize pojedinih dimenzija održivog razvoja, u radu je predstavljen općeniti model održivog razvoja otočnih zajednica. Model pretpostavlja integrirani razvoj lokalne zajednice na načelima održivosti, definira ključne procese i odrednice razvoja, te se može primjenjivati u kontekstu ruralnog razvoja i razvoja otoka, uzimajući u obzir specifičnosti pojedine lokalne zajednice.

Ključne riječi: održivi razvoj zajednice, otočna zajednica, jadranski otoci, posttranzicijsko razdoblje.

\footnotetext{
${ }^{1}$ Dr. Sc. Željka Tonković, Department of Sociology, University of Zadar, Obalja kralja Petra Krešimira IV, br. 2, 23000 Zadar, Croatia; e-mail: zeljka.tonkovic@unizd.hr

${ }^{2}$ Dr. Sc. Jelena Zlatar, Institute for Social Research in Zagreb, Amruševa 8/III, 10000 Zagreb, Croatia; e-mail: zlatar.jel@gmail.com
} 


\section{Introduction}

Since the Brundtland Commission report in 1987, the concept of sustainable development has been defined as "the development which meets the needs of present-day generations while ensuring the same needs can be met by future generations" (WCED, 1987). Even though national governments and international organizations play a major role in achieving the main goals of sustainable development, a lot of important steps are taken at the local level. Sustainable communities can be defined as those communities which "meet the economic needs of their residents, enhance and protect environment and promote more humane local societies" (Bridger, Luloff, Brennan, 2006: 404). Based on the theory of sustainable community development, this paper is a case study of the place Postira on the island of Brač (Croatia) and presents a positive example of sustainable community development on islands in the posttransition social context.

\section{Theoretical background}

The paper is theoretically based on the concept of sustainable development and its four pillars: economic, ecological, social and cultural. The concept of sustainability initially referred to environmental or ecological sustainability, that is, the carrying capacity of the environment and its long-term ability to cope with the pollution and use of natural resources (Starc, 1994). As academic discussions developed, it was argued that apart from environmental aspects other domains of sustainability should be included, namely "economic sustainability" and "social sustainability" (UNDPCSD, 1996; UNDSD, 2000; UNECOSOC, 2001).

Economic sustainability comprises the economic growth and efficiency essential for the longterm satisfaction of material needs, social security and consumption opportunities. Besides, a satisfactory level of economic welfare helps resolve ecological problems and makes investment in new technologies possible (Spangenberg, 2004). Unlike economic and ecological domains, which dominated the sustainable development debate, social and cultural sustainability were, until recently, often neglected and under-theorised. Social sustainability mostly comprises employment rate, education, training, income, social capital and social security (Spangenberg, 2004; Colantonio, 2009; Chiu, 2004; Boström, 2012, Murphey, 2012). Although there is no consensus on the definition and indicators of social sustainability, one example of a more comprehensive definition is provided by Colantonio (2009), saying that social sustainability is how "individuals, communities and societies live with each other and set out to achieve the objectives of development models which they have chosen for themselves, also taking into account the physical boundaries of their places and planet earth as a whole" (Colantonio, 2009: 872).

Lately, cultural sustainability has also come into focus (Day, 1998; Hawkes, 2001; Cochrane, 2005; Vallega, 2007; Sacco, Blessi and Nuccio, 2009; Miltojević and Ilić-Krstić, 2011). Since cultural values shape the very perception of development, sustainable development comprises powerful cultural sustainability, capable of implementing and carrying out development goals (Hawkes, 2001). As the fourth pillar of sustainability, culture encompasses both "documented culture" (William, 1965) of historical monuments and cultural heritage and "culture of everyday life" of the local community. In other words, the cultural dimension of sustainable development includes "the ability to preserve cultural identity along with enabling changes in accordance with cultural values" (Miltojević and Ilić-Krstić, 2011: 35).

Moreover, according to some authors, the multidimensional nature of sustainability requires the inclusion of different domains of sustainability and assessment of interactions between them in order to achieve a holistic approach (Throsby, 2008; O'Toole, Wallis and Mitchell, 2006; Spangenberg, 2004). Such suggestions imply that there are parallels between the processes of ecological, economic and socio-cultural development (Throsby, 2008). Interactions between these dimensions are best visible in concrete situations at the local level and this is why theoretical frameworks of sustainable development should take into account specific contexts, geographical and temporal scales (Lehtonen, 2004). 


\begin{tabular}{|c|c|c|}
\hline & Indicators & References \\
\hline \multirow[t]{3}{*}{$\begin{array}{l}\text { Economic } \\
\text { sustainability }\end{array}$} & $\begin{array}{l}\text { - growth of GDP/capita } \\
\text { - inflation rate }\end{array}$ & Spangenberg, 2004 \\
\hline & $\begin{array}{l}\text { - national income } \\
\text { - inflation rate } \\
\text { - average earnings }\end{array}$ & Fraser et al., 2006 \\
\hline & $\begin{array}{l}\text { - local economic diversity } \\
\text { - self-reliance }\end{array}$ & Bridger et al., 2006 \\
\hline \multirow[t]{3}{*}{$\begin{array}{l}\text { Ecological } \\
\text { sustainability }\end{array}$} & $\begin{array}{l}\text { - environmental space use } \\
\text { - protected nature reserves }\end{array}$ & Spangenberg, 2004 \\
\hline & $\begin{array}{l}\text { - emissions of greenhouse gases } \\
\text { - natural habitats and key species } \\
\text { - household waste }\end{array}$ & Fraser et al., 2006 \\
\hline & $\begin{array}{l}\text { - protection of biological diversity } \\
\text { - reduction in the use of energy } \\
\text { - waste product management and recycling }\end{array}$ & Bridger et al., 2006 \\
\hline \multirow[t]{3}{*}{$\begin{array}{l}\text { Social } \\
\text { sustainability }\end{array}$} & $\begin{array}{l}\text { - fair distribution of income } \\
\text { - equality of rights } \\
\text { - access to social infrastructure } \\
\text { - social cohesion } \\
\text { - sense of community } \\
\text { - quality of life, happiness and well-being }\end{array}$ & Boström, 2012 \\
\hline & $\begin{array}{l}\text { - social interactions/social networks } \\
\text { - participation in collective groups and networks } \\
\text { - community stability } \\
\text { - pride/sense of place } \\
\text { - safety and security }\end{array}$ & Dempsey et al., 2011 \\
\hline & $\begin{array}{l}\text { - social justice } \\
\text { - access to public services } \\
\text { - participation in the decision-making process } \\
\text { - community empowerment }\end{array}$ & Bridger et al., 2006 \\
\hline \multirow[t]{2}{*}{$\begin{array}{l}\text { Cultural } \\
\text { sustainability }\end{array}$} & $\begin{array}{l}\text { - well-being } \\
\text { - creativity } \\
\text { - diversity } \\
\text { - innovation }\end{array}$ & Hawkes, 2001 \\
\hline & $\begin{array}{l}\text { - access to cultural participation } \\
\text { - cultural heritage preservation } \\
\text { - cultural diversity }\end{array}$ & Throsby, 2008 \\
\hline
\end{tabular}

Tab 1. Four pillars of sustainability: selected indicators.

These considerations correspond to the theory of sustainable community development (SCD) (Bryant, 1995; Bridger, Luloff, Brennan, 2006; Bridger and Luloff, 1999; Newman and Dale, 2005; Roseland, 2000). Sustainable community development can be defined as "a process by which the community attempts to influence the processes affecting various activities in the community in order to improve the quality of life of its residents in an enduring way through identifying and pursuing strategies that are compatible with the natural environment, socially and culturally acceptable and economically feasible" (Bryant, 1995: 180). According to previous studies and theoretical insights, Hamstead and Quinn (2005) point to the central features of the theory of SCD, which together form a normative framework for practical applications: economic diversity and self-reliance; social justice and community empowerment; ecological sustainability. Taking into account the importance of local culture, we suggest that cultural vitality of a place as the fourth pillar of sustainability, should be regarded as one of the central features of the SCD theory. Accordingly, the aim of this paper is to illuminate the relationships 
between the four pillars of sustainability at the local level and to provide an integrating framework based on the empirical example.

\section{Sustainable development of Croatian islands: previous research and case study selection}

Islands are often considered vulnerable because of specific challenges they face, including their relative isolation, a sensitive environment, a high dependency on seasonal activities and external inputs, demographic imbalance and insufficient public infrastructure (Baldacchino and Pleijel, 2010). According to the Croatian national strategy of sustainable development, great biodiversity, clean sea and relatively few pollutants are the main advantage of coastal regions and islands, whereas the biggest problem of islands are economic and demographic decline caused by depopulation and loss of active and fertile population. Other problems include the lack of urban and/or industrial wastewater treatment devices, excessive fishing resulting in the decline of fish stocks, uncontrolled tourism development and consequent overbuilding (Lay and Šimleša, 2012).

Previous research indicates numerous common determinants of island communities development as well as their diversity. Thematically, previous research and academic literature on Croatian islands mostly deal with depopulation of islands (Lajić, Podgorelec, Babić, 2001; Fabjanović, 1990; Friganović, 2001; Graovac, 2004; Mišetić, 2010; Lajić and Mišetić, 2013), quality of living and daily migrations of islanders (Lajić, Podgorelec, Babić, 2001; Podgorelec, 2008; Podgorelec and Klempić-Bogadi, 2013), sustainable development guidelines for economy (Defilipis, 2001; Šimunović, 1994), agriculture (Radinović, 2001) and tourism (Zlatar, 2008; Petrić and Pranić, 2010; Kuveždić, 2001) and implementation of sustainable island development projects (Mackelworth and Carić, 2010; Mackelworth, 2007; Stubbs and Starc, 2007). The analysis of the existing academic literature shows that the sustainable development theory is the dominant one (Mackelworth and Carić, 2010; Šulc and Valjak, 2012; Zlatar, 2008; Kuveždić, 2001; Petrić and Pranić, 2010), while some studies use the systems theory (Šimunović, 1994), historical institutionalism (Stubbs and Starc, 2007) or the common pool resource theory (Mackelworh, 2007). According to Starc (2001), the phenomenon of Croatian islands is still insufficiently researched and more specific development measures are required. Furthermore, due to the diversity of island communities and islands themselves, in-depth local case studies are necessary (Stubbs and Starc, 2007). Starting from the theory of sustainable community development, the paper draws on previous research about the sustainable development of Croatian islands and expands it using the analytical framework of the SCD theory.

Beside depopulation and lack of human capital, the development of islands in the pre-transition and transition period has been hindered by abandonment of traditional activities, such as agriculture and fishing and closing down of manufacturing industry. Specific island problems have been recognized which resulted in the National Programme of Island Development (NPID, 1997) and Island Act (1999). Considering the fact that sustainable island economy should include tourism, industry and agriculture at the same time (Šimunović, 2007), positive examples of local development are those islands and local communities which have achieved balanced economic development, based on the renewal of traditional agriculture, "mixed economy" and family farming (Radinović, Par, Gugić, 2004). In fact, one of development goals stated by NPID was to diversify the structure of island economy. However, island communities in Croatia are more and more tourism-oriented (Podgorelec and Klempić-Bogadi, 2013). Though tourism is a great contribution to the local economy and community, it has not prevented population decline because of its random development and no infrastructure investment which is required if the young are to stay on islands (Podgorelec and Klempić-Bogadi, 2013). In addition, administrative division of islands into two or more municipalities, without joint planning and coordination, inefficient local institutions and overly politicized decision-making, stand in the way of successful implementation of sustainable island development projects (Stubbs and Starc, 2007). Also, sustainable development projects have often been considered a threat to the mass tourism promotion policy and the "short-term 'business as usual' development model" (Mackelworth and Carić, 2010). Therefore some authors (Starc, 2002) argue that the Adriatic 
islands are at the crossroads, choosing between sustainable and unsustainable development policies.

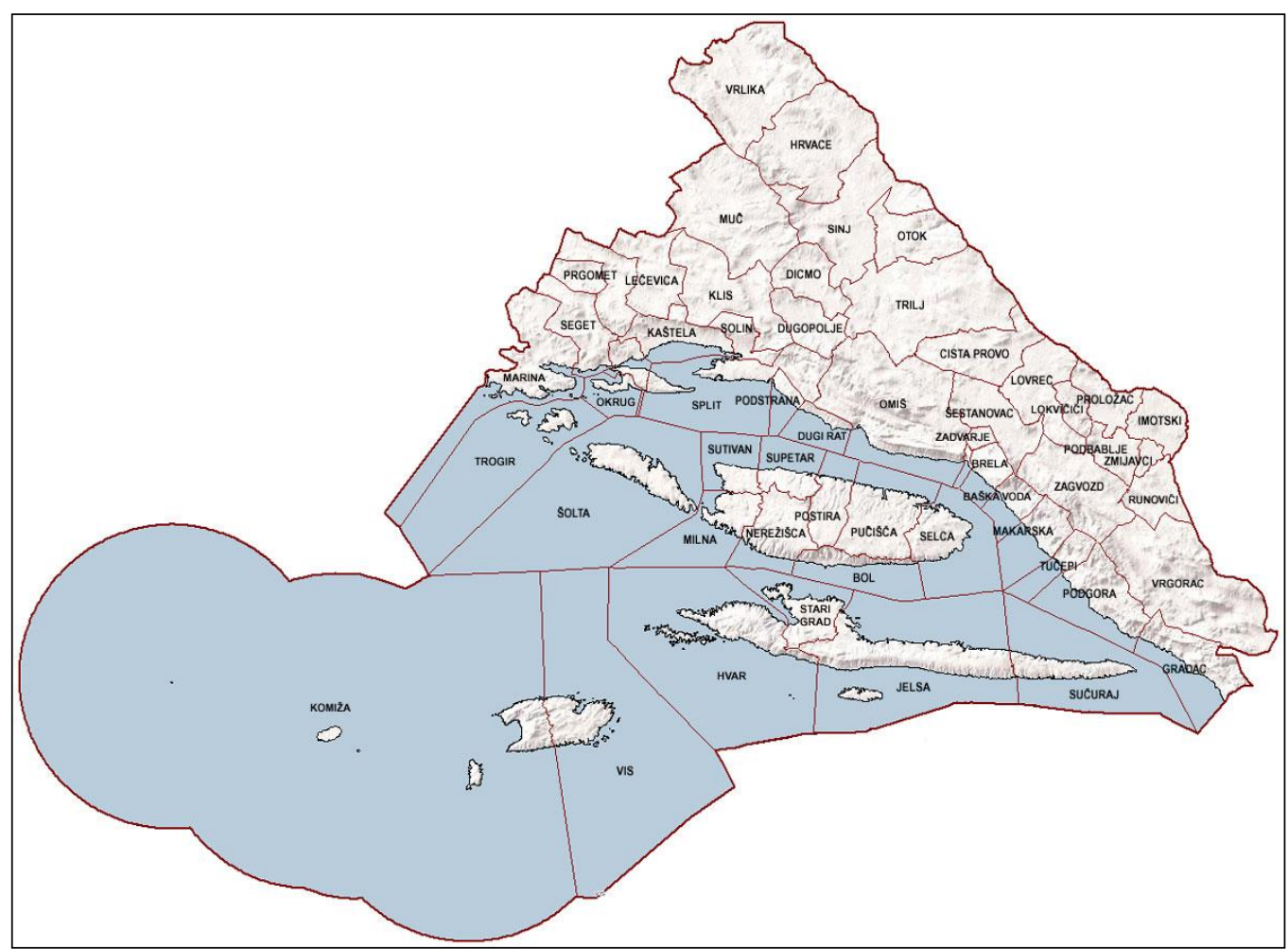

Fig 1. Split-Dalmatia County with islands. Source: http://www.dalmacija.hr/\%C5\%BDupanija/Karta

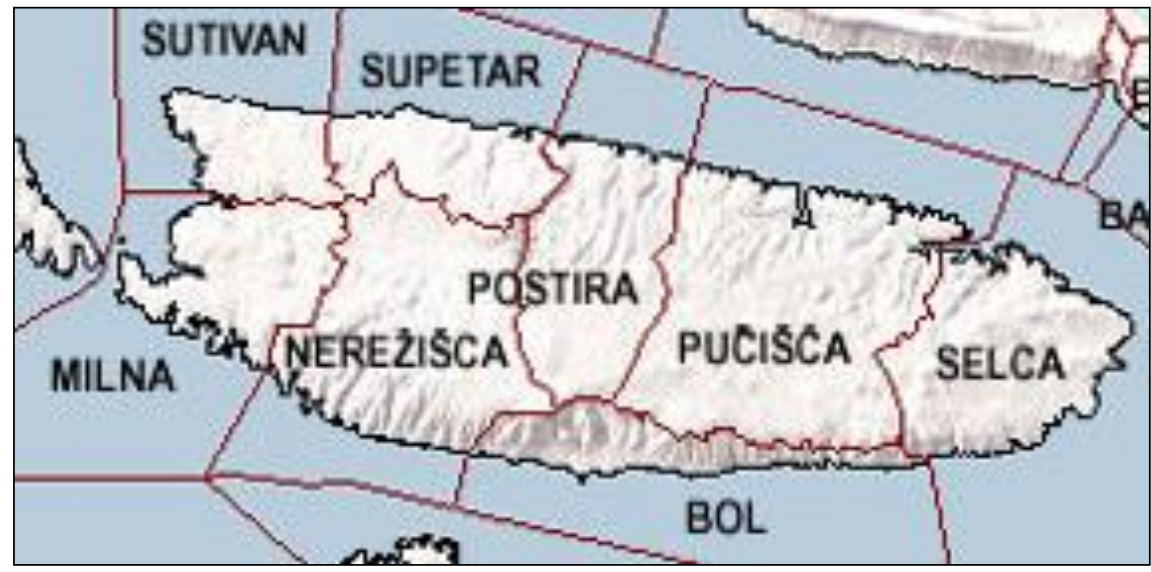

Fig 2. Location of Postira Municipality within the island of Brač. Source: http://www.dalmacija.hr/\%C5\%BDupanija/Karta

Brač is the third largest Adriatic island, with a population of 12,663 people (Central Bureau of Statistics). Historically, island economy has always been based on agriculture, especially viticulture and olive growing, animal husbandry and fishing, but also stonemasonry, trade and tourism. While tourism has gained importance from the 1960s onwards (Kuveždić, 2001), olive growing, as the second source of income, has remained one of the most important economic activities even today. In the pre-transition period the whole island was one municipality; today there are eight administrative units, one town and seven municipalities. There is some coordination between municipal mayors, but it is rather informal and without adequate joint planning (Stubs and Starc, 2007). Some of the island settlements are mostly rural (Povlja), while others are more urban and have developed mass tourism (Bol). Postira (from Latin pastura - pasture), a place on the north coast of the island, with a population of 1,559 people, has been chosen for our case study because of its balanced economic development and simultaneous growth of marine fishing industry, tourism and agriculture. 


\section{Aims and methods}

On the basis of theoretical concepts mentioned above, this paper examines sustainable community development in Postira, focusing on the four domains of sustainability (economic, ecological, social and cultural) and using the case study method. Case study is an empirical inquiry that investigates a contemporary phenomenon within its real-life context and relies on multiple sources of evidence (Yin, 2003). According to Denzin (1989), case studies provide a deeper understanding of the social processes in a locality or localities by analyzing a case or several cases. Because of this, case studies have increasingly been used in sustainable development research (Mackelworth and Carić, 2010; Fraser et al, 2006; Scott, Park and Cocklin, 2000).

The paper is based on the hypothesis that Postira is a positive example of a sustainable island community, because of the diversified economic structure, which includes all key sectors of the island economy. The first aim of this study is to examine the development of Postira given the dimensions of sustainable development and to point out their relationships. The second objective is to put forward specific guidelines for further sustainable development of Postira. The third one is to provide a comprehensive and holistic framework for the local development analysis, based on the empirical example.

This case study was done at two levels. The first level was the analysis of secondary sources, documents and statistical data; the second level was the qualitative research carried out using semi-structured interviews with the key actors of local development. Bearing in mind that what constitutes sustainable development at a local and regional scale depends on the worldviews, values and attitudes held by the local community (O'Toole, Wallis and Mitchell, 2006), the qualitative analysis was used in order to explore and understand local development practices along with local community values and attitudes.

Taking into account the main features of the sustainable community development theory, Bridger et al. (2006) claim that a starting point for empirical investigation should be identification of the social fields and local stakeholders that are active in some or all dimensions of the sustainable community development. In order to include various social fields and local stakeholders, 26 face-to-face interviews with key actors were conducted, including representatives of local authorities, tourist board representatives, apartment owners, restaurant and coffee bar owners, farmers and crop growers from the agricultural cooperative, craftsmen, olive growers, cultural workers, artists and NGO leaders. The process of data analysis involved coding of transcripts, categorizing the codes into the main themes and, lastly, identifying the relationships to broader conceptual and theoretical framework from the literature (Denscombe, 2007; Creswell, 2007). The data analysis was driven by the main research question: in what ways do the indicators of local development in Postira reflect the principles of sustainability and its four domains?

\section{Research results}

\subsection{Economic domain}

Several economic factors point to the local economic diversity and self-reliance, which are indicators of sustainable community development (Bridger et al., 2006). First of all, employment structure data show that $25.2 \%$ of people are employed in the primary sector, $36.1 \%$ in the secondary sector and $38.7 \%$ in the tertiary sector. This demonstrates the importance of fish processing industry and agriculture but also the balance of all employment sectors. A diversified economy, which is the result of a hundred-year old tradition of fishing, fish processing industry and agriculture, is a special advantage of Postira. In Postira various sectors of economy are connected in the way which allows for optimal economic growth of the island and mitigation of the effects of the economic recession.

In Postira, industry, agriculture and tourism are considered equally important and useful for economic growth of the place. (representative of agricultural cooperative) 
The development index of the municipality reaches $95 \%$ of the national average (MRDEUF, 2010), mostly because of the low unemployment rate (6.9\%) and positive population trends ${ }^{3}$. Postira also has a strong export orientation, mostly due to its blue fish processing industry "Sardina Postira Ltd." which employs about 300 people (SDC, 2011). The qualitative analysis also demonstrates the importance of industry because of a large number of people employed in it and the safe income it provides throughout the year.

Although in socialism tourism was well developed in Postira, a significant growth in tourist traffic started only in the 1990s and today most tourists stay in private accommodation and small hotels. Twenty interviewees (out of 26) agree that tourism potential, second in importance, has not been fully recognized. Family tourism prevails due to the lack of tourist facilities but its season is very short and it does not promote the place. Private accommodation is the dominant type of accommodation which does not place Postira very highly on the tourist map. Hotel owners and managers therefore observe that hotels brand Postira as a destination rather than the other way round. All respondents agree it is important to have a longer season, develop the infrastructure and new types of tourism: sports, agro and eco-tourism. Also there is a consensus about mass tourism: it should not be the primary goal of Postira as it might have a devastating effect on natural resources and the place identity.

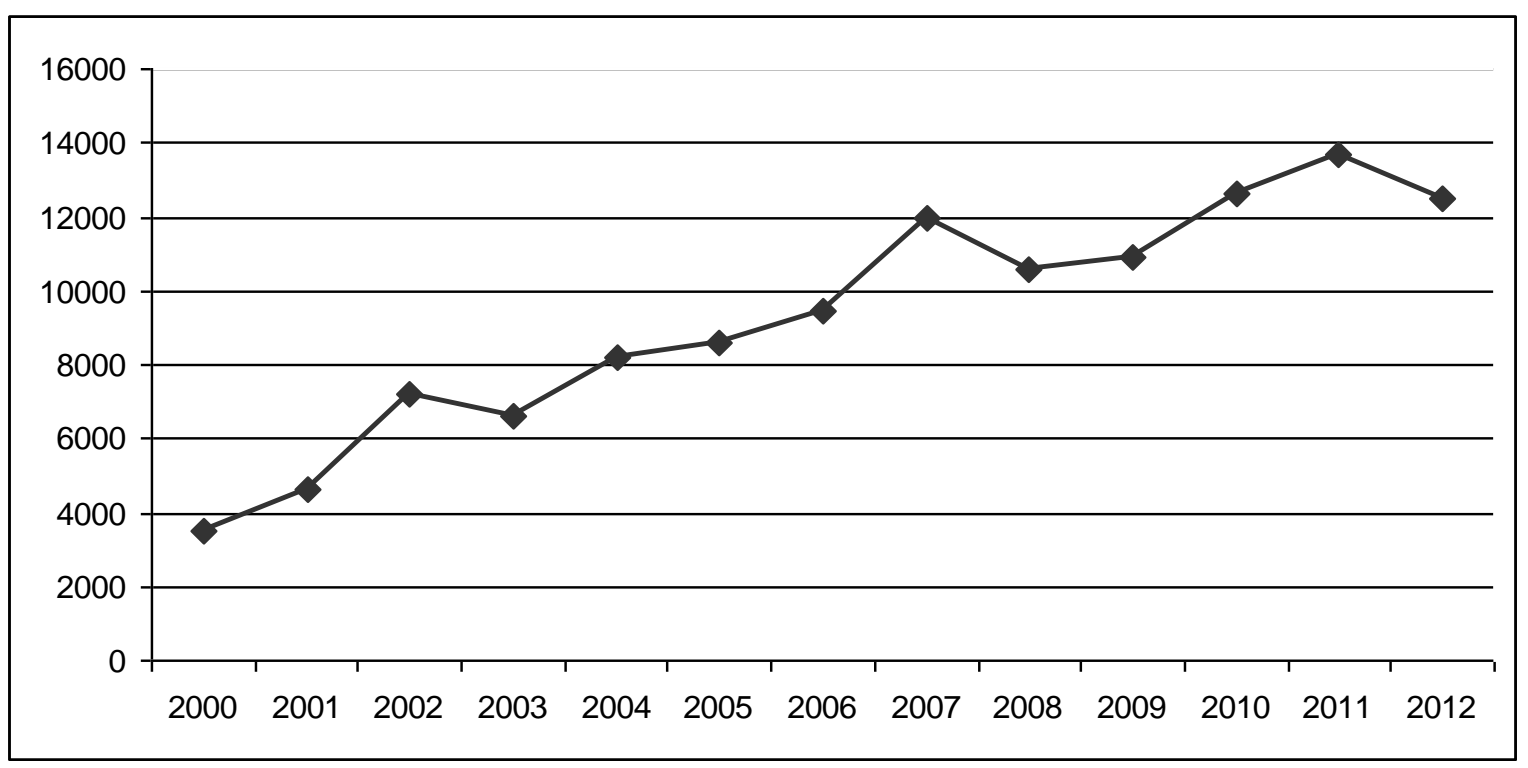

Fig 3. Arrivals in Postira since 2000. Source: Croatian Bureau of Statistics.

When agriculture is considered, today $56.5 \%$ of households own agricultural land and $29.4 \%$ grow grapes and olives (CBS, 2001). However, these are all small plots of land and land consolidation and product branding are relevant for agricultural development (Vlahović, 2005). Olive oil production has a vast market potential which, as olive growers point out, is not fully used because there is no recognizable brand. Since Croatia joined the EU the market has broadened and branding of autochtonous local products has become a priority. Another problem are unresolved and complicating ownership issues on islands (Defilippis, 2001), also present in Postira, which cause problems for new initiatives (e.g. cultivation of abandoned olive groves, restoration of old family houses and their conversion to attractive accommodation for tourists).

Between 10 and $12 \%$ of the total Croatian production of olive oil comes from Postira. There are about 400,000 trees in Postira. It is a huge market potential. But, compared with Italy, Greece, Spain or Portugal - our chances are slim (apartment owner and olive grower)

\footnotetext{
${ }^{3}$ Development index consists of 5 principal indicators: income per capita, unemployment rate, budget revenues of the municipality, city or county per capita, population trends, education rate (MRDEUF, 2010).
} 
Although until now local actors have played the most important part in economic growth, foreign investors are frequently mentioned as crucial for further development. There is not nearly enough private initiative and entrepreneurship, especially in the tertiary sector. The reason might be the fact that most local people, beside their regular employment, have additional activities (olive growing, tourism) and do not like taking risk in entrepreneurship.

\subsection{Ecological domain}

All economic activities in Postira owe their sustainable development potential to well-preserved natural resources, clean sea, beautiful beaches and the coast which has been spared excessive or illegal building. The olive-sheep system allows for ecological development of olive growing in Postira. Some local products (Postira agricultural co-op olive oil, Postira sardines, brand Fini soaps) and a few small producers are recognized on the market for their ecological awareness. Eco and agro tourism thrive on the protection and preservation of the environment. A hotel manager says that clean sea and natural surroundings are the comparative advantage of Postira and the place has to avoid environment devastation.

We need the former slogan of the Croatian Tourist Board: the Mediterranean as it used to be. That is precisely what tourists want: seven days of piece and quiet, good domestic food, clean sea, a comfortable hotel, autochtonous products. No amusement parks and such things. Anybody can have them. But once you pollute your clean sea, there is no going back. The damage is irreparable (hotel manager)

In Postira there is a modern water supply and sewerage system. Attention was paid to environment protection and energy efficiency when the new factory was built. There are separators for industrial and rain wastewater which prevent uncontrollable soil and subterranean waters pollution. Municipal waste disposal and sorting is provided in front of the factory. The factory cooling system uses carbon dioxide which cuts the energy consumption and is more eco-friendly than freons. Biomass is to be used as fuel in industrial production (Nadilo, 2013: 369). In addition, tuna farming in the south-west of the island does not present a threat for the environment.

Various actors (local government, agricultural cooperative, individual producers, hotel owners) are responsible for environmental protection. Tourist workers, local producers of olive oil and representatives of the agricultural cooperative advise a stronger connection between tourism and agriculture, in order to improve conditions for ecotourism and agritourism development. However, the most important is the role of the municipal government. Interviews with the local government representatives show their ecological awareness: they put the eco-ethno village of Dol, the second oldest settlement on the island and a protected historical unit, high on the list of development priorities. The same goes for some geographically protected indigenous local products (Hrapoćuša cake) or those soon to become protected (Brač sheep cheese). However, the local community funds are limited and the current administrative division of island in eight municipalities is an obstacle for development projects, such as agricultural irrigation systems or land consolidation.

Postira has not been affected by aggressive apartment building like the rest of the Croatian coast and large islands, partly because of the fish processing factory. However, three interviewees mention landscape devastation caused by the construction of the industrial zone and new tourist zones. Although research results show the continuous effort of the local community to protect the environment and there are plans for further reduction in the use of energy and more effective waste product management, there are still possible threats to the environment. Among them, the biggest threat might be a new hotel with more than 200 rooms which the spatial plan envisions at the former location of the sardine factory, on the waterfront. The research shows that only two respondents share the concern whereas the majority considers new accommodation facilities desirable for the long-term economic development of Postira. 


\subsection{Social domain}

Our research demonstrates that Postira is a socially sustainable and vital community. First of all, demographic data indicate demographic stability and a favourable population age structure. In recent history, unlike in other places on the island of Brač, there has been no significant population growth or loss in Postira. Social cohesion and local identity have thus been maintained. However, there is a fear that in the near future the young, the middle-aged and the educated might leave the island causing the loss of human capital, which is the key element of development.

\section{There is this idea of leaving the place. There is no population decline, but there is no growth either. People dream of returning to Postira when they retire (owner of a hotel and agricultural business)}

Social sustainability indicates permanent efforts to improve the quality of living ${ }^{4}$ by ensuring equal opportunities for everyone to access public services. Most key actors (22 out of 26 respondents) that the local government initiates and is responsible for the most important activities regarding the development of Postira and the Municipal Mayor plays the leading role.

According to Dempsey et al. (2011), participation in groups and networks is an important indicator of social sustainability. Our research shows that in Postira there are several civil society organizations ${ }^{5}$ which preserve cultural heritage, promote tourism, protect the environment and traditional values. They are the community's cohesive force which brings together different actors, encourages their communication and enriches the whole place with various activities essential for growth and development.

Frequent communication and cooperation among local actors are important both for the promotion of the community development goals and the community empowerment enhancement (Bridger et al., 2006). The majority of our respondents (20 of them) state that such communication exists at the local level, especially among the municipal government, the tourist board, the fish processing factory and the agricultural co-op. Six respondents, however, hold a different view. According to them, the synergy of all relevant actors is only formal, with few activities or clear goals. For example, the local population is not sufficiently involved in decision-making processes because major decisions are made by the municipal government and the Mayor. In addition, it seems that, in spite of the existing social capital in Postira, there is certain reluctance when it comes to doing business together. A few successful examples have only been the result of personal contacts and affinity. Two business initiatives have failed: individual apartment owners joining the Apartment Owners Association and the Brač hotels project initiated by some hotel owners. On the other hand, in agriculture, especially in olive growing, things look better: the local co-op and local olive growers work very well together and there is a local association of olive growers.

According to eight our respondents, young people's attitudes are considered as a big problem: they are rather passive and not particularly interested in traditional activities. Job security in industry or tourism is not motivating enough for them to stay on the island and the lack of social and cultural events makes them leave the place early. Poor involvement in local activities can partly be explained by poor infrastructure which does not meet their needs. Also, there is no development planning, no investment in young people's education for future jobs in agriculture, tourism and other activities. This problem is typical for all rural areas of Croatia where there is a strong tendency of leaving. Postira Municipality development strategy clearly states the need to work on everyday existence issues of the young (Šimunović et. al, 2013).

\footnotetext{
${ }^{4}$ Thanks to the efforts of the local government in the last eight years much has been done to raise the quality of living. For instance, wastewater problem has been solved, a pharmacy, a kinder garden and a mortuary have opened. The Municipality and the agricultural co-op buildings have been renovated, the seaside promenade and the port enlarged.

${ }^{5}$ There are Hrapoćuša and Kogula, two associations for the promotion of art and culture, olive-growers' association and rental housing association.
} 


\subsection{Cultural domain}

Cultural diversity, cultural heritage protection and access to cultural participation are some of the indicators of cultural sustainability and vitality of a local community (Throsby, 2008). Culturally vital local communities create and sustain public places for cultural events and protect cultural resources such as historical monuments (Hawkes, 2001; Vallega, 2007). Our research shows that people in Postira possess a strong sense of place and awareness about the importance of preservation of tangible and intangible cultural heritage. According to our respondents, intangible cultural heritage of their community is connected to the Christian tradition and attachment to traditional activities such as agriculture and fishing.

In Postira there are two associations, Hrapoćuša and Kogula, which preserve cultural heritage and environment, renovate infrastructure facilities and old buildings, protect traditional products and organize cultural and educational activities. Some cultural events are organized by a local NGO and the parish office. Thanks to this cooperation, in the last few years a few religious monuments have been renovated and have become tourist attractions. This has not only improved the tourist offer but has also strengthened community cohesion and cultural identity.

Cultural life in Postira is more vibrant during the tourist season. However, five respondents mention there is no large indoor space for cultural events except the Pastoral Centre which is open for cooperation but, being a center of Christian spirituality, it is inappropriate for some kinds of events. Although in socialism there was a cinema in Postira in the former Community center built by contributions from all citizens, in the period of transformation and privatization of social property, the center was converted into a hotel. There is no public library in Postira except for the school library and church records.

As a teenager I used to play in the Community center with my band. Today, people meet in coffee bars. Public space is shrinking and this is a problem (cultural worker)

One goal of sustainable development on islands should be to preserve the traditional culture and identity. This can be done in many ways: cultural tourism development, protection of local products and (non)material heritage. A lot of our respondents believe that Postira and Brač have all pre-conditions for successful cultural tourism but also a number of serious problems: lack of professional staff, not enough attractive cultural events, insufficient coordination and flow of information. Positive examples are products with protected designation of origin and events which promote the local culture and enrich the tourist offer. ${ }^{6}$ The Municipality of Postira development strategy is sensitive to cultural development.

\section{Discussion and Conclusions}

As shown in some previous research (Mackelworth and Carić, 2010), successful implementation of national and international sustainable development policies depends on the social context and local specificities. By focusing on one island community, key actors and their perceptions of various aspects of sustainable development, this case study tried to emphasize the principal characteristics of a sustainable island community. They are: balanced economic growth, developed sense of community and continuous care for the protection of natural resources and traditions such as olive growing. Relying mostly on local initiatives, Postira Municipality effectively deals with problems typical for the Adriatic islands: depopulation, abandonment of traditional activities, deindustrialization and mass tourism. The result is balanced and sustainable development in all four domains, as proven by the qualitative analysis results. Moreover, this case study has shown that all four domains of sustainability are closely connected. Cultural identity is attached to the environment and agriculture. Preserved natural environment allows for economic sustainability based on balanced development of agriculture, marine fishing industry and tourism. Similarly, social sustainability and vitality of the community thrives on the economic potential of the place and low unemployment rate. The comparison with previous case studies of local communities on Croatian islands (Zlatar, 2008; Lajić, Podgorelec, Babić, 2001; Podgorelec and Klempić-Bogadi, 2013; Mackelworth and Carić, 2010; Šulc and

\footnotetext{
${ }^{6}$ For instance, there are annual cultural events: Oblica fest (the festival of olive oil) and Hrapoćuša Days (named after the special cake made in the village of Dol).
} 
Valjak, 2012) shows that Postira is a specific example because the place successfully copes with most issues threatening the sustainable development of islands.

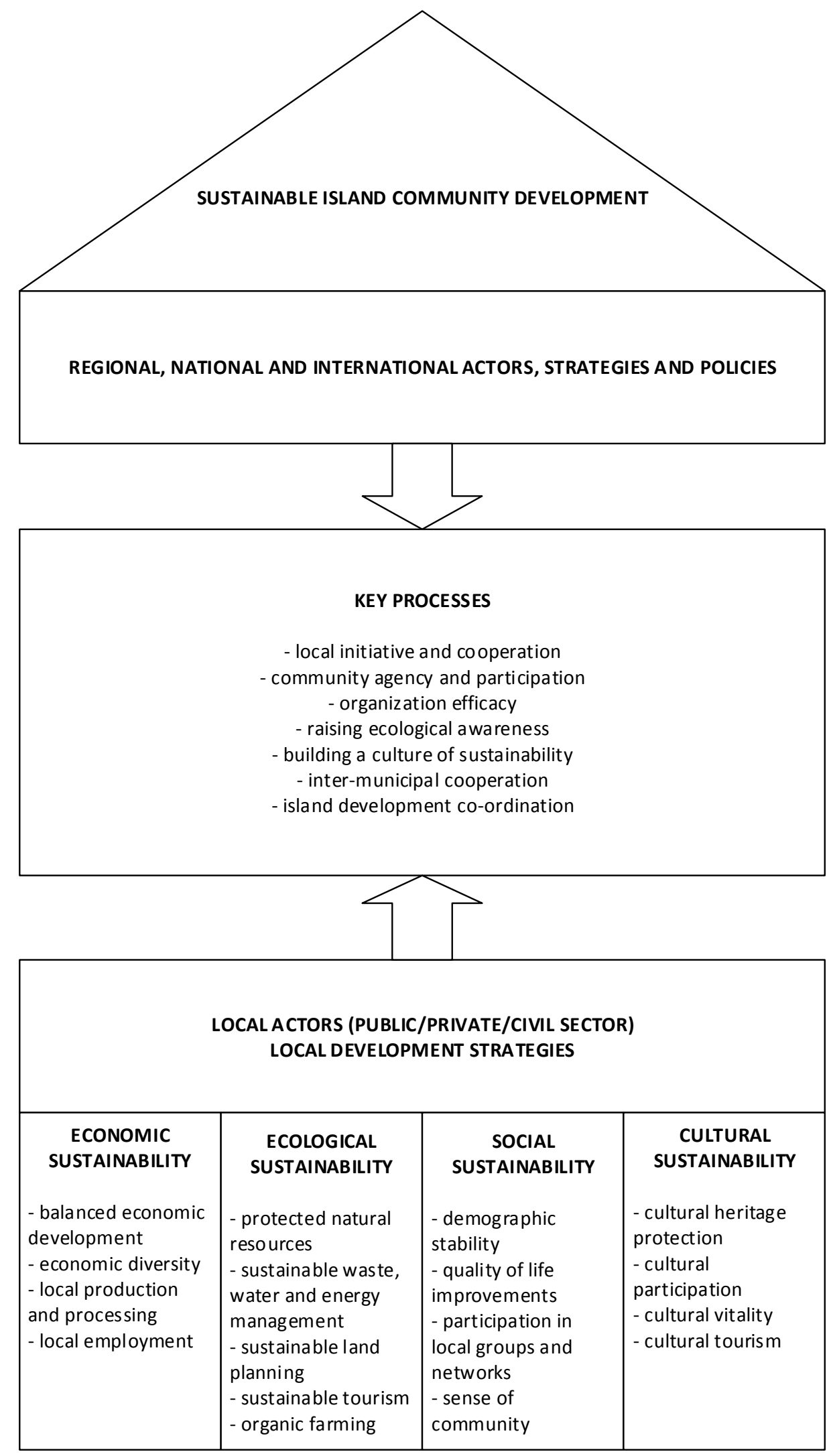

Fig 4. A framework for sustainable island community development. 
This paper has tried to analyze the success of one sustainable island community while at the same time highlighting the problems. There are various obstacles on the road to sustainability. For instance, although Postira has a vast potential for sustainable tourism, it is not fully used. Moreover, if we look at the present development trends and local strategies in Postira (Šimunović et al., 2013), we can observe the tendency towards a considerable increase of accommodation facilities on the one hand and commitment to "responsible forms of tourism", such as ecotourism and rural tourism, on the other. In other words, Postira is also "on the crossroads" (Starc, 2002) of different development models. Compared to other places on the island, Postira stands in the middle position, between Bol (mass tourism) and Povlja (tendency towards agrotourism, Zlatar, 2008).

Another problem is the disproportionate development of places on the island which is a direct result of the non-existent broader strategic planning. The research shows strategic goals of sustainable development are best achieved when the whole local community is involved, and this is in line with some previous studies (Mackelworth and Carić, 2010). However, this case study points out that local action alone is not enough. Although the existing system of local government in Croatia allows every municipality on the island to develop on its own, more efficient communication and coordination among local governments is needed for the development of infrastructure, tourism and economy in general and to position the whole island in the EU. For example, local governments' limited funds and separate spatial plans obstruct important development projects on islands, such as agricultural irrigation systems or land consolidation. Also, islands need better traffic connections and closer economic partnership ${ }^{7}$. Finally, the state should get more involved in island development, not only in infrastructure projects but all relevant sustainable development projects (Mackelworth and Carić, 2010).

The conclusions, although based on the example of one Croatian island community, can also be applicable to other rural and island communities which are facing the challenge of further development after decades of institutional reforms and transition which has often meant deindustrialization and abandonment of traditional production activities. Therefore, on the basis of this case study we propose a general framework for sustainable development of island communities (see Figure 4). According to the proposed framework, sustainable development at the local level is possible if there is a holistic and balanced relationship between the key dimensions of sustainability. The model further indicates that the implementation of sustainable development policies is based on local initiative and requires community agency and participation of the local population, as demonstrated by the case of Postira. In addition to local initiatives, cooperation at the inter-municipal, regional and state level is needed in order to accomplish sustainable community development. In other words, effective integration of topdown and bottom-up approaches to sustainable development strategies would be an ideal solution.

Furthermore, the existing problems indicate that, in future planning, strategic goals need to be defined for the entire island. Regarding sustainability of local communities on the Adriatic islands in general, it is necessary to brand autochthonal products and thus enhance the identity of the Adriatic islands as a tourist destination. As island communities are traditionally tourism oriented, new types of sustainable and responsible tourism are welcome. Balanced economic growth would prevent island depopulation and loss of educated population. Tourism, agriculture and industry need to respect the environment, taking care of the carrying capacity of each place. However, when it comes to specific development goals and strategies, the identity and authenticity of each island has to be respected, as is pointed out by many authors and at the very beginning of the article (Mackelworth and Carić, 2010). Therefore, this framework can provide only general guidelines for the sustainable island development. Even so, we feel this model is a contribution or at least an addition to existing sustainability models.

\footnotetext{
7 This was recognized in Postira where the Centre for Integral Development of Central Dalmatian Islands was founded in 2013 with the main aim to encourage communication among local governments.
} 
[1] Baldacchino, G. \& Pleijel, C. (2010). European Islands, Development and the Cohesion Policy: A Case Study of Kökar, Åland Islands. Island Studies Journal, 5(1), 89 - 110.

[2] Boström, M. (2012). A missing pillar? Challenges in theorizing and practicing social sustainability. Sustainability: Science, Practice \& Policy, 8(1), 3 - 14.

[3] Bryant, C. (1995). The role of local actors in the transforming the urban fringe. Journal of Rural Studies 11, 255 - 267. DOI: 10.1016/0743-0167(95)00020-N.

[4] Bridger, J. \& Luloff, A. E. (1999). Toward an interactional approach to sustainable community development. Journal of Rural Studies, 15(4), 377 - 387. DOI: 10.1016/S07430167(98)00076-X.

[5] Bridger, J. C., Luloff, A. E. \& Brennan, M. A. (2006). Achieving sustainable communities. In McKinstry, R. B., Ripp, C. M. \& Lisy, E., Eds., Biological conservation handbook: State, local, and private protection of biological diversity, (pp. 393 - 416). Washington (DC): Environmental Law Institute.

[6] Chiu, R. L. H. (2004). Socio-Cultural Sustainability of Housing: a Conceptual Exploration. Housing, Theory and Society, 21(2), 65 - 76. DOI: 10.1080/14036090410014999.

[7] Cochrane, P. (2005). Exploring cultural capital and its importance in sustainable development. Ecological Economics 57(2), 318-330. DOI: 10.1016/j.ecolecon.2005.04.012.

[8] Colantonio, A. (2009). Social sustainability: a review and critique of traditional versus emerging themes and assessment methods, in Horner, M., Price, A., Bebbington, J. \& Emmanuel, R., (eds.) SUE-Mot Conference: conference proceedings (pp. 865 - 885). Loughborough: Loughborough University.

[9] Council of the European Union (2006). Review of the EU Sustainable Development Strategy, Brussels, 10917/26 June 2006. Retrived from http://register.consilium.europa.eu/pdf/en/06/st10/st10917.en06.pdf (accessed 10 August 2013).

[10] Creswell, J. W. (2007). Qualitative inquiry and research design. Choosing among five approaches. Sage: Thousand Oaks, London, New Delhi.

[11] Croatian Bureau for Statistics (DZS) (2013). Statistical Yearbook for 2012. Zagreb: Croatian Bureau for Statistics.

[12] Croatian Bureau for Statistics (DZS) (2011). Tourism in seaside resorts and municipalities in 2011. Zagreb: Croatian Bureau for Statistics.

[13] Day, G. (1998). Working with the grain? Towards sustainable rural and community development. Journal of Rural Studies 14(1), 89-105. DOI: 10.1016/S0743-0167(97)000405.

[14] Defilippis, J. (2001). Economic development of Croatian islands. Sociologija Sela 39(1/4), 83 - 95.

[15] Dempsey, N., Bramley, G., Power, S. \& Brown, C. (2011). The social dimension of sustainable development: Defining urban social sustainability. Sustainable development 19(5), 289 - 300. DOI: 10.1002/sd.417.

[16] Denscombe, M. (2007). The Good Research Guide For Small Scale Research Projects. Maidenhead: Open University Press,.

[17] Denzin, N. (1989). The research act ( $3^{\text {rd }}$ ed.). Englewood Cliffs (NJ): Prentice Hall.

[18] ESPON (2010). The ESPON 2013 Programme. The Development of the Islands European Islands and Cohesion Policy (EUROISLANDS): Interim Report. http.//www.islandscommission.org/pub/news/75_interim_report_010210.pdf (accessed 11 October 2012.) 
[19] European Environment Agency (2000). Common framework for sector-environment integration indicators - EEA paper for the meeting of the EPRG expert group on indicators, Copenhagen, 13 - 14 April 2000.

[20] Fabjanović, Đ. (1991). Changes in the dynamics and structure of the inhabitants on the island of Brač. Croatian Geographical Bulletin 53(1), 75 - 94.

[21] Fraser, E., Dougill, A., Mabee, W., Reed, M. \& McAlpine, P. (2006). Bottom up and top down: analysis of participatory processes for sustainability indicator identification as a pathway to community empowerment and sustainable environmental management, Journal of Environmental Management 78(2), 114 - 127.

DOI: 10.1016/j.jenvman.2005.04.009.

[22] Friganović, M. A. (2001). O demografskoj problematici hrvatskih otoka na Jadranu. Sociologija sela 39(1/4), 37 - 59.

[23] Graovac, V. (2004). Island on the verge of extinction. The example of Zadar islands, Croatia. Geoadria 9(2), 183 - 210.

[24] Government of the Republic Croatia (2013). Croatian Tourism Development Strategy until 2020. http://narodne-novine.nn.hr/clanci/sluzbeni/2013_05_55_1119.html (accessed 10 September 2013).

[25] Hamstead, M. P. \& Quinn, M. S. (2005). Sustainable Community Development and Ecological Economics: Theoretical Convergence and Practical Implications. Local Environment, 10(2), 141 - 158. DOI: 10.1080/1354983052000330743.

[26] Hawkes, J. (2001). The Fourth Pillar of Sustainability: Culture's Essential Role in Public Planning. Flinders Lane: Common Ground Publishing.

[27] Island Act (1999). Official Gazette of the Republic of Croatia 34/1999, Zagreb.

[28] Kuveždić, H. (2001). Tourism development on the island of Brač. Acta Geographica Croatica 34, 127 - 140.

[29] Lajić, I., Podgorelec, S. \& Babić, D. (2001). Islands - to stay or to leave? A study on daily commuting from Šibenik islands. Zagreb: Institute for Migration.

[30] Lajić, I. \& Mišetić, R. (2013). Basic demographic processes on the Kvarner islands 1991 2011. Geoadria 18(1), 71 - 92.

[31] Lay, V. \& Šimleša, D. (2012). Development of Croatia in the light of sustainable development. Library of Centre for Research on Integral Sustainability and Sustainable Development - Book 3. Zagreb: Institute for social sciences Ivo Pilar.

[32] Lehtonen, M. (2004). The environmental-social interface of sustainable development: capabilities, social capital, institutions. Ecological Economics 49(2), 199-214. DOI: 10.1016/j.ecolecon.2004.03.019.

[33] Mackelworth, P. C. \& Carić, H. (2010). Gatekeepers of island communities: exploring the pillars of sustainable development, Environmental Development and Sustainability 12(4), 463 - 480. DOI: 10.1007/s10668-009-9205-4.

[34] Mackelworth, P. C. (2007). Convergence of marine protected area policy with common pool research theory, a case study: The Lošinj Dolphin Reserve, Croatia. [Unpublished doctoral thesis]. London: University College London.

[35] Milinković, B. (2000). Research on the Croatian village and agriculture in the transition period 1990 - 1999. Sociologija sela 1/2 (147/148), 169 - 245.

[36] Mišetić, R. (2010). Central Dalmatia: an area of differentiated demographic development (1961-2001). Migracijske i etničke teme 26(3), 297-319.

[37] Murphey, K. (2012). The social pillar of sustainable development: a literature review and framework for policy analysis. Sustainability: Science, Practice \& Policy, 8(12), 15 - 29. 
[38] Nadilo, B. (2013). The new Sardina factory in Postira - a story our economy can learn from. Građevinar, Journal of the Croatian Association of Civil Engineers 65(4), 361 - 371.

[39] National island development programme (1997.) http://www.europskifondovi.eu/sites/default/files/dokumenti/Nacionalni_program_razvitka_otoka.pdf (accessed 20 October 2013.)

[40] Newman, L. \& Dale, A. (2005). The role of agency in sustainable local community development. Local environment 10 (5), 477 - 486. DOI: 10.1080/13549830500203121.

[41] O'Toole, K., Wallis, A. \& Mitchell, B. (2006). Local perceptions of sustainability indicators: issues of scale and implications for management. Rural Society 16(1), pp. 25 - 46.

[42] Petrić, L. \& Pranić, L. (2010). The attitudes of the island local community towards sustainable tourism development - the case of Stari Grad, island Hvar, In Favro, S. \& Brebbia, C. A., eds., Island sustainability (pp. 77 - 88). Southampton: WIT Press.

[43] Podgorelec, S. \& Klempić-Bogadi, S. (2013). Cities sank the islands - changes in small island communities. Zagreb: Institute for Migration and Ethnic Studies.

[44] Podgorelec, S. (2008). Growing old on an island. The quality of life of the elderly on Croatian islands. Zagreb: Institute for Migration and Ethnic Studies.

[45] Postira Municipality (2011). Official Gazette of Postira Municipality, 16 (1/11), Postira.

[46] Radinović, S. (2001). Development of agriculture on Central Dalmatian islands. Sociologija sela 39, 1/4 (151/154), 97 - 108.

[47] Radinović, S., Par, V. \& Gugić, J. (2004). Socio-economic processes in the family farming in Dalmatia. Društvena istraživanja 4/5 (72/73), 825 - 842.

[48] Report on economic and financial developments in Split-Dalmatia County in 2011 (2012), Split-Dalmatia County, Department of Economy, Development and European Integration, Split.

[49] Roseland, M. (2000). Sustainable community development: integrating environmental, economic, and social objectives. Progress in Planning, 54(2), 73 - 132. DOI: 10.1016/S0305-9006(00)00003-9.

[50] Sacco, P. L., Nuccio, M. \& Blessi, G. T. (2009). Cultural Policies and Local Planning Strategies: What Is the Role of Culture in the Local Sustainable Development? The Journal of Arts Management, Law and Society 39(1), 45 - 63. DOI: 10.3200/JAML.39.1.45-64.

[51] Scott, K., Park, J. \& Cocklin, C. (2000). From 'sustainable rural communities' to 'social sustainability': giving voice to diversity in Mangakahia Valley, New Zealand. Journal of Rural Studies 16(4), 433 - 446. DOI: 10.1016/S0743-0167(00)00018-8.

[52] Spangenberg, J. H., (2004). Reconciling sustainability and growth: criteria, indicators, policies. Sustainable Development 12(2), 74 - 86. DOI: 10.1002/sd.229.

[53] Split-Dalmatia County (SDC) (2011). Strategy for Split-Dalmatian county development 2011 - 2013. Split: Rerasd.

[54] Starc, N. (1994). Development, sustainability and evaluation of investment enterprise. In Klarić, Z., ed., Towards sustainable tourism development in Croatia (pp. 67 - 81). Zagreb: Institute for tourism.

[55] Starc, N. (2001). Managing island development. Sociologija sela 39, 1/4 (151/154), 15 - 36.

[56] Starc, N. \& Stubbs, P. (2007). Islander vs. the state? Participation in island development programmes in Croatia. Paris: $47^{\text {th }}$ Congress of the European Regional Science Association - Local governance and sustainable development.

[57] Šimunović, I., Ramić, D., Šore, N. \& Šemanović, M. (2013). Development strategy of municipality of Postira from 2014 to 2020. Postira: Centre for integrative development of Central Dalmatian islands. 
[58] Šimunović, I. (2007). Living on the island. In: Šimunović, I., ed., Brač almanac 22. Edition Bošković, Split/ Brački zbornik d.o.o., Supetar.

[59] Šimunović, I. (1994). Islands and socio-economic processes. Društvena istraživanja 12 13 (3), 4-5, 451 - 466.

[60] Šulc, I. \& Valjak, V. (2012). Protected areas as a factor in sustainable development of Croatian islands - the example of Mljet. Croatian Geographical Bulletin, 74(1), 161 - 185.

[61] The Ministry of Regional Development and EU Funds (MRDEUF) (2010). Values of development index and standardised indicators compared to the local development index. http://www.mrrfeu.hr (accessed 10 August 2013.)

[62] The Ministry of Environmental Protection, Physical Planning and Construction (MEPPC). (2009). Strategy for Sustainable Development of the Republic of Croatia. Official Gazette of the Republic of Croatia 30/2009.

[63] Throsby, D. (2008). Linking Cultural and Ecological Sustainability. The International Journal of Diversity in Organisations, Communities and Nations, 8(1), 15 - 20.

[64] United Nations Division for Sustainable Development (UNDSD), UN Department of Economic and Social Affairs. (2000). Indicators of Sustainable Development, Framework and Core Set, Draft of September 20th, 2000. New York: United Nations.

[65] United Nations Economic and Social Council (UNECOSOC) (2001). Implementing Agenda 21 - Report of the Secretary General. New York: United Nations.

[66] United Nations Division for Sustainable Development. Department of Policy Co-Ordination and Sustainable Development (UNDPCSD). (1996). Indicators of Sustainable Development, Framework and Methodologies. New York: United Nations.

[67] United Nations Environment Programme (UNEP). (2005). Mediterranean strategy for sustainable development. A framework for environmental sustainability and shared prosperity. New York: United Nations.

[68] Vallega, A. (2007). The role of culture in island sustainable development, Ocean and Coastal Management 50(5-6), 279 - 300. DOI: 10.1016/j.ocecoaman.2007.02.003.

[69] Williams, R. (1965). The Long Revolution. Harmondsworth: Penguin.

[70] World Commission on Environment and Development (WCED). (1987). Our Common Future, UN Documents Cooperation Circles, http://www.un-documents.net/wced-ocf.htm, accessed 12 December 2012.

[71] Yin, R. (2003). Case study research, design and methods. Thousand Oaks (CA): Sage. 